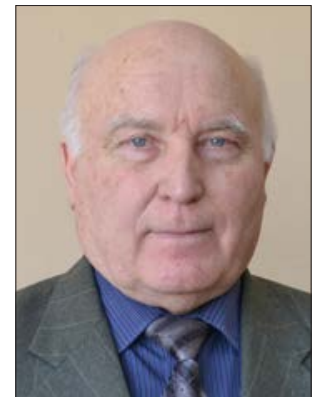

Viktor A.

Dubinin,

Дубінін Віктор Андрійович

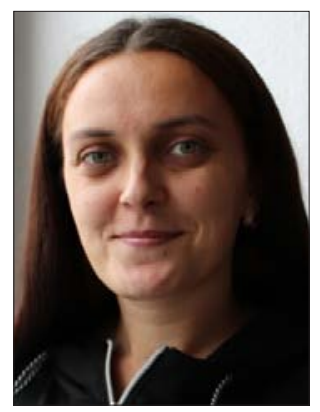

Albina V. Brodovska, Бродовська Альбіна Вікторівна
УДК 504

\section{TECHNOGENIC AND ENVIRONMENTAL RISKS IN THE OPERATION OF THE AMMONIA PIPELINE ON THE EXAMPLE OF THE MYKOLAIV REGION}

\section{ТЕХНОГЕННО-ЕКОЛОГІЧНІ РИЗИКИ ПРИ ЕКСПЛУАТАЦІЇ АМІАКОПРОВОДУ НА ПРИКЛАДІ МИКОЛАЇВСЬКОЇ ОБЛАСТІ}

\author{
DOI https:// doi.org/ 10.15589/smi2020.1(13).8
}

Viktor A. Dubinin

Дубінін Віктор Андрійович, канд. воєн. наук, доц.

viktor.dubinin@nuos.edu.ua

ORCID: 0000-0001-9458-5887

Albina V. Brodovska

Бродовська Альбіна Вікторівна, магістр brodovska199@gmail.com

Admiral Makarov National University of Shipbuilding, Mykolayiv

Національний університет кораблебудування імені адмірала Макарова, м. Миколаїв

Abstract. The purpose of the work is to study the technical parameters of the ammonia pipeline "Togliatti-Odessa", to determine the factors that increase the risk of accidents, their consequences for the population and the environment, and to model the accident on sections of the ammonia pipeline in Mykolaiv region.

The analysis of technical characteristics of the Togliatti-Odessa ammonia pipeline is carried out, physicochemical and toxic properties of ammonia are defined. Factors that increase the risks of accidents, their consequences for the population and the environment have been identified. Potential accidents during the operation of the ammonia pipeline, features of the leakage of ammonia on the soil surface, its entry into the atmosphere and further spread are considered. Simulation of accident on sites of the ammonia pipeline in the Nikolaev area is carried out. On the example of the section of the ammonia pipeline passing under the Southern Bug River near the villages of Trikhaty, Pisky and Sebine, long-term forecasting of the consequences of accidents was carried out, the size of chemical contamination zones and human losses were calculated. The general information and technical characteristics of the ammonia pipeline are given, potential accidents on the ammonia pipeline and ways to counteract it are considered.

The number of potential losses among the population of each of the nearby villages as a result of the accident on the ammonia pipeline was calculated. The method of forecasting the consequences of spillage (emission) of chemically hazardous substances in accidents at industrial facilities and transport, developed and approved by the Ministry of Emergencies of Ukraine, was used for the calculation. It is established that the expected losses among the population can be considered moderate, as the number of potential losses for the village. Trihati -60 people; with. Sands - 39 people; with. Sebino - 176 people. In each case, it is $35 \%$ of the population in the affected area. Ways to counteract the effects of ammonia on humans and provide information on the effects of ammonia on humans and other living organisms, such as plants. It is revealed that the considered methods of forecasting ecological risk do not have a single approach to the assessment of the consequences of accidents and long-term forecasting of accidents on the main ammonia pipeline near settlements is not given much attention.

Key words: ammonia pipeline; properties of ammonia; accidents; chemically dangerous object; zones of infection; forecasting.

Анотація. Метою роботи є дослідження технічних параметрів аміакопроводу «Тольятті-Одеса», визначення факторів, які підвищують ризики виникнення аварій, їх наслідки для населення та навколишнього середовища, та проведення моделювання аварії на ділянки аміакопроводу в Миколаївський області.

Проведено аналіз технічних характеристик аміакопроводу Тольятті-Одеса, визначено фізико-хімічних і токсичних властивостей аміаку. Встановлено фактори які підвищують ризики виникнення аварій, їх наслідки для населення та навколишнього середовища. Розглянуті потенційні аварії при експлуатації аміакопроводу, особливості витоку аміаку на поверхню грунту, потрапляння його у атмосферу та подальше поширення. Проведено моделювання аварії на ділянки аміакопроводу в Миколаївський області. На прикладі відрізку аміакопроводу, що проходить під річкою Південний Буг поблизу сіл 
Трихати, Піски та Себіне проведено довгострокове прогнозування наслідків аварій, розраховано розміри зон хімічного зараження та людські втрати. Наведено загальну інформацію та технічні характеристики аміакопроводу, розглянуто потенційні аварії на аміакопроводі та способи протидії ним.

Проведено розрахунок кількості потенційних втрат серед населення кожного з поблизу розташованих сіл в результаті аварії на аміакопроводі. Для розрахунку було використано методику прогнозування наслідків розливу (викиду) хімічно небезпечних речовин при аваріях на промислових об'єктах і транспорті, розроблену і затверджену Міністерством з надзвичайних ситуацій України. Встановлено, що очікувані втрати серед населення можна вважати середньо-важкими, оскільки, кількість потенційних втрат для с. Трихати - 60 чол; с. Піски - 39 чол; с. Себіно - 176 чол. У кожному з варіантів це $35 \%$ населення у зоні ураження. Наведено способи протидії дії аміаку на людей та наведено інформацію щодо дії аміаку на людей та інші живі організми, наприклад рослини. Виявлено, що розглянуті методики прогнозування екологічного ризику не мають єдиного підходу до оцінки наслідків аварій та довгостроковому прогнозуванню аварій на магістральному аміакопроводу поблизу населених пунктів не приділяється значної уваги.

Ключові слова: аміакопровод, властивості аміаку, аварії, хімічно небезпечний об'єкт, зони зараження, прогнозування.

\section{References}

[1] Melnyk SV, Tsabiev OM, Bondar IO (2015) Forecasting the environmental risk for the city of Odessa in the event of an emergency release of ammonia from the port plant. Proceedings of Odessa Polytechnic University, 2015. Issue. 2 (46). Pp. 165-172.

[2] Grabar OV, Likhachova VV, Rysenko GO (2010) Ecological safety and reliability of operation of the main ammonia pipeline. Bulletin of the Automobile and Road Institute, 2010, № 2 (11). Pp. 170-174.

[3] Zatynaichenko DO Forecasting of air and Dnieper pollution in case of accident on the ammonia pipeline "Togliatti-Odessa" Rescue work during emergency response. Part 1: Guide. For the general Ed. VN Wheat. - K.: Oснова, 2006. $-240 \mathrm{c}$.

[4] "How the ammonia pipeline is arranged". TRANSAMMIAC website URL: Risk assessment of accidents on the Togliatti-Odessa main ammonia pipeline

http://transammiak.com/index.php?location=ammiak\&sess=45893e507d39b753a7073ec4a9d36705

[5] Dadonov Yu. A., Degtyarev DV, Kruchinina IA, Lisanov MV, Burdachev VE Labor safety in Industry. Science and Technology, 2003. P. 27-30.

Постановка проблеми. Урахування техногенних та екологічних ризиків стає в останні роки одним із основоположних з огляду на те, що аварії на об'єктах підвищеної небезпеки тягнуть за собою загибель, погіршення здоров'я населення, додаткові фінансові витрати на усунення негативного впливу. У зв'язку 3 тим, що щороку кількість аварій на хімічних підприємствах усього світу збільшується, зростає і величина ризику для людей. Причинами збільшення кількості аварій є наднормативна експлуатація обладнання, його корозія, несправність контрольно-вимірювальної апаратури та помилки обслуговуючого персоналу.

Аміак, або ж нітрид водню $\left(\mathrm{NH}_{3}\right),-$ необхідна у хімічному виробництві, але вкрай отруйна і небезпечна речовина. 3 огляду на те, що аміакопроводу притаманні всі вище перераховані причини аварій, виникає гостра необхідність у проведенні аналізу стану аміакопроводу і довгострокового прогнозування наслідків аварії.

Аналіз останніх досліджень і публікацій. Слід зазначити, що матеріали дослідження оцінки наслідків аварій, пов'язаних із виробництвом і транспортуванням аміаку, публікуються не часто.

Заслуговують на увагу публікації авторських колективів: С.В. Мельник, О.М. Цабієв, І.О. Бондар «Прогнозування екологічного ризику для міста Одеси у разі аварійного викиду аміаку з Припортового заводу»;
О.В. Грабар, В.В. Лихачова, Г.О. Рисенко «Екологічна безпека та надійність експлуатації магістрального аміакопроводу», а також російських авторів Ю.А. Додонова, Д.В. Дегтярева, І.А. Кручиніна, М.В. Лисанова, В.Е. Бурдачева «Оценка риска аварий на магистральном аммиакопроводе «Тольятти - Одесса».

Потрібно звернути увагу на те, що розглянуті методики прогнозування екологічного ризику не мають єдиного підходу до оцінки наслідків аварій. Не приділяється увага довгостроковому прогнозуванню аварій на магістральному аміакопроводі поблизу населених пунктів.

Мета дослідження - проаналізувати технічні параметри аміакопроводу «Тольятті - Одеса». Звернути увагу на фактори, які підвищують ризики виникнення аварій, їхні наслідки для населення та навколишнього середовища.

Провести моделювання аварії на ділянки аміакопроводу в Миколаївський області.

Основний матеріал (результати). Аміакопровод трубопровід, призначений для транспортування аміаку. У світі існує не більше десятка аміакопроводів, що виходять за межі технологічних майданчиків хімічних підприємств. Аміакопровод «Тольятті - Одеса» найбільш потужний аміакопровод у світі. Його транспортні можливості становлять до 2,5 млн тонн на рік. Побудований у 1979 р., він унікальний за технічним рішенням і призначенням. 
Експлуатацію російської ділянки аміакопроводу здійснює ВАТ «Трансаміак», українську ділянку аміакопроводу експлуатує Українське державне підприємство «Укрхімтрансаміак», кінцеву ділянку аміакопроводу - Одеський припортовий завод у м. Южне, де аміак завантажується в танкери й експортується на ринки Європи й Америки.

Довжина трубопроводу 2414км, ізних 1 031,189км проходять по території України. У середньому кожні 5,2 км аміакопроводу розділені на секції запірною арматурою - постами секціонування, які у разі необхідності можуть бути оперативно перекриті.

При тиску до 35 атмосфер за температури $4^{\circ} \mathrm{C}$ аміак перебуває у рідкому агрегатному стані. Для запобігання корозії в аміак додано $0,4 \%$ води. Діаметр виготовленої у Франції труби - 355 мм, товщина 8 мм, вона пролягає на глибині 1,4 м (порівняно 3 0,8 м для нафтопроводів). У місцях перетину водоймищ і вологого грунту трубопровід має подвійну трубу товщиною 13 мм із шаром азоту. Задля безпеки аміакопровод прокладено не ближче, ніж за 1 км до населених пунктів (у США, за наявності кількох аміакопроводів, такої вимоги немає).

Рідкий аміак - висококонцентроване азотне добриво, містить 82,3\% азоту. Це небезпечна хімічна речовина (НХР), суміш його парів із повітрям за певних концентраціях може бути вибухонебезпечною.

Тиск насичених парів аміаку залежить від температури фаз, яка приблизно рівна температурі довкілля. Аміак характеризується невеликим коефіцієнтом об'ємного стиснення порівняно 3 коефіцієнтом об'ємного розширення, тому при повному заповненні посудини тиск його парів із підвищенням температури може досягти великих значень.
Якщо при $0^{\circ} \mathrm{C}$ ємність повністю заповнити аміаком, то при підвищенні температури до $30^{\circ} \mathrm{C}$ його тиск може досягти 51,5 МПа, що в кілька разів перевищує міцність зварних швів і металевого корпусу ємності.

Аміак діє на слизові оболонки верхніх дихальних шляхів і очей. У разі легкого отруєння з'являються незначна сухість, першіння та біль у горлі, кашель, захриплість, чхання, нудота. При гострому отруєнні аміаком виникає ускладнене дихання, сильний кашель, втрата голосу, спазм голосової щілини, задуха, почервоніння обличчя, пітливість, сльозотеча, набряк повік, блювота та запаморочення.

За високих концентрацій аміаку у повітрі виробничих приміщень 3'являється різкий біль у горлі, сльозотеча та сильна різь в очах, у потерпілого спостерігається сильне нервове збудження, розлад дихання, спад серцевої діяльності, похолодання кінцівок. Вдихання аміаку за таких концентрацій може викликати смерть від рефлекторної зупинки дихання і спазму голосової щілини.

За період експлуатації аміакопроводу було зареєстровано 43 випадки витоків аміаку. Усі витоки були незначні та виявлені лише при розкопках.

Розглянемо розподіл витоків аміаку за елементами аміакопроводу:

- $30 \%$ витоків виявлено на зворотних клапанах (у т. ч. 10 випадків витоків спричинено дефектом заводського лиття корпусів зворотних клапанів);

- $6,6 \%$ загального числа витоків зумовлено порушенням герметичності кульових кранів;

- $\quad$ виявлено 2 випадки мікровитоків аміаку через тіло металу лінійної частини аміакопроводу внаслідок заводського браку.

Виявлялися витоки при профілактичних оглядах стану підземної частини зворотних клапанів і кульо-

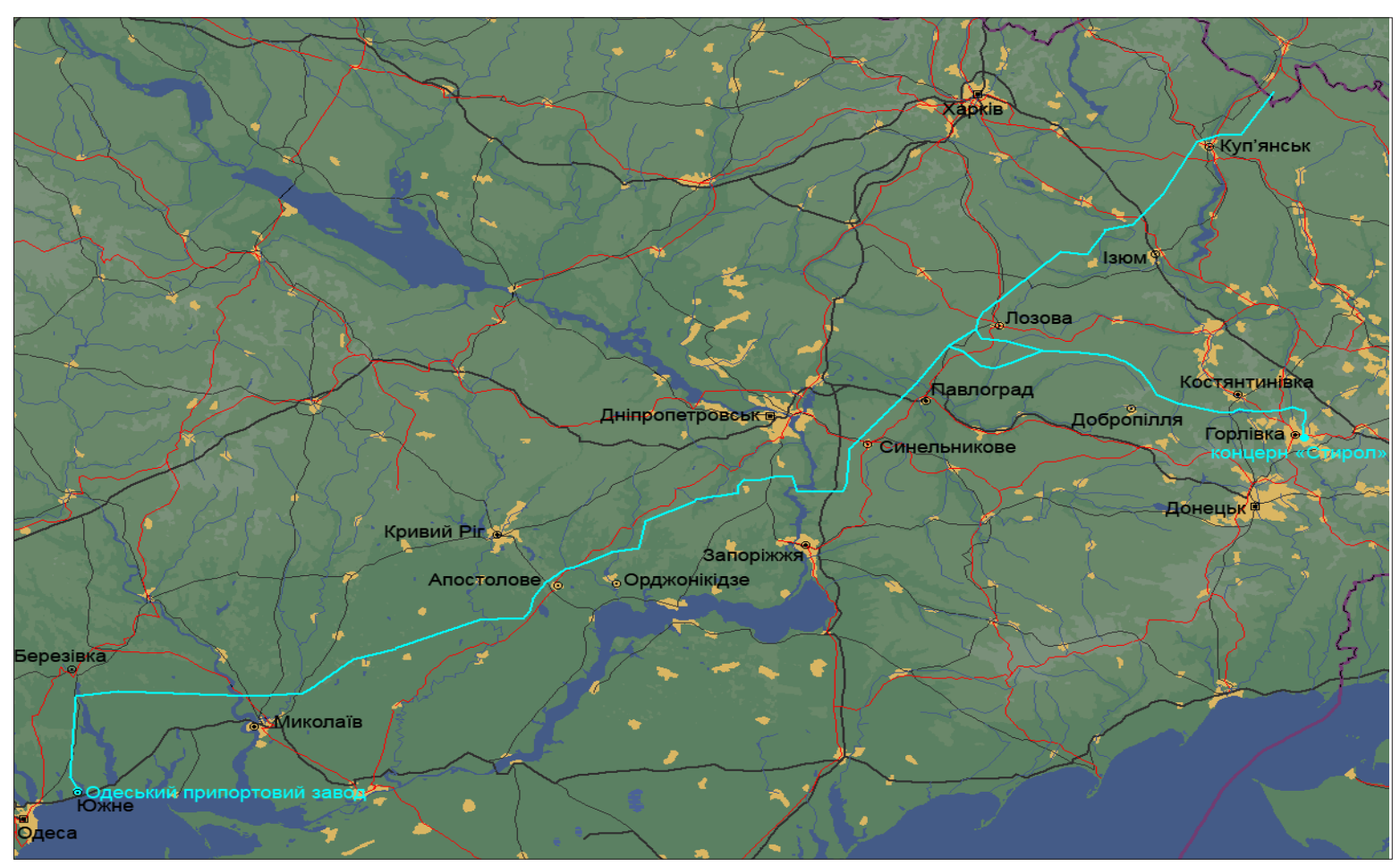

Рис. 1. Схема української частини аміакопроводу 
вих кранів при їх розкопці та за специфічним запахом аміаку в місцях витоку під час обходів персоналу.

Задля запобігання ситуації аварійної зупинки насосів використовують зворотні клапани.

Для забезпечення безпечних режимів роботи магістрального аміакопроводу передбачено автоматизовану систему управління технологічним процесом транспортування рідкого аміаку на базі електронних засобів контролю та мікропроцесорної техніки.

Для оперативного виявлення можливих витоків аміаку та вживання відповідних захисних заходів передбачають регулярний автоматичний вимір значень тиску та витрат рідкого аміаку на насосних станціях. Відключення аварійних ділянок здійснюється автоматичним закриттям кранів на постах секціонування при значеннях тиску аміаку, нижчих за значення, передбачені проектною документацією.

При розгерметизації аміакопроводу аміак унаслідок малої швидкості фільтрації у вологій землі майже увесь витікатиме на поверхню грунту.

Внаслідок контакту аміаку із грунтом, температура якого $13^{\circ} \mathrm{C}$, буде відбуватися випаровування аміаку до 5 кг на 1 м $^{2}$ грунту. У разі витоку аміаку на спаханий грунт ця величина може досягти значень 10 кг/м².

Внаслідок аварії на аміакопроводі 6 серпня 2013 р. на заводі ПАТ «Концерн Стирол», розташованому в місті Горлівка Донецької області, відбувся викид аміаку у повітря, витекло та випарувалося в атмосферу 700 т аміаку. Аерозольна хмара покрила територію в 40 км². Довкола місця аварії на площі у 4,3 га зелень повністю почорніла. На площі 11,66 км² лісова рослинність отримала середній ступінь ушкодження, а на площі 21,17 км² - легкий ступінь ушкодження.

Ще одна аварія сталася внаслідок розгерметизації аміакопроводу взимку за температури повітря $-1{ }^{\circ} \mathrm{C}$ та швидкості вітру 10-12 км/г. Аерозольна хмара простяглася в південному напрямі на від-

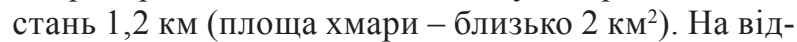
стані 1,2 км від витоку із підвітряного боку можна було ходити без протигазів, відчувався лише різкий запах аміаку.

Така суперечність наведених даних про відстань і площу поширення аерозольної хмари при аварійних витоках аміаку пояснюється відсутністю достовірних даних про концентрацію аміаку на кордонах поширення аерозольної хмари. Також відсутні дані про використання приладів для визначення концентрацій аміаку в атмосфері.

При надходженні аміаку в атмосферу насамперед якнайшвидше визначають місце розташування, напрямок вітру та поширення аміачної хмари, проводиться евакуація людей із прогнозованої зони поширення небезпечних концентрацій. Кордони поширення хмари аміаку визначають візуально, переважно за запахом. Поріг сприйняття людиною парів аміаку - 35 мг/ $\mathrm{M}^{3}$, а мінімальна концентрація, небезпечна для життя, становить 350 мг/ $\mathrm{M}^{3}$.

Площа і відстань поширення хмари аміаку значною мірою залежать від атмосферних умов (температури, швидкості вітру, вологості повітря та ін.), які у багатьох випадках при витоках відрізнялися.

Транспортування рідкого аміаку у зазначеному аміакопроводі «Тольятті - Одеса» відбувається і по території Миколаївської області. Зокрема, у цій статті буде розглянуто відрізок, що проходить під річкою Південний Буг поблизу сіл Трихати, Піски та Себіно (рис. 2). Для цієї ділянки буде змодельовано аварію, розраховано розміри зони ураження та можливі людські втрати.

Розглянемо моделювання викиду аміаку на ділянці, де аміакопровід перетинає р. Південний Буг (рис. 2, рис. 3).

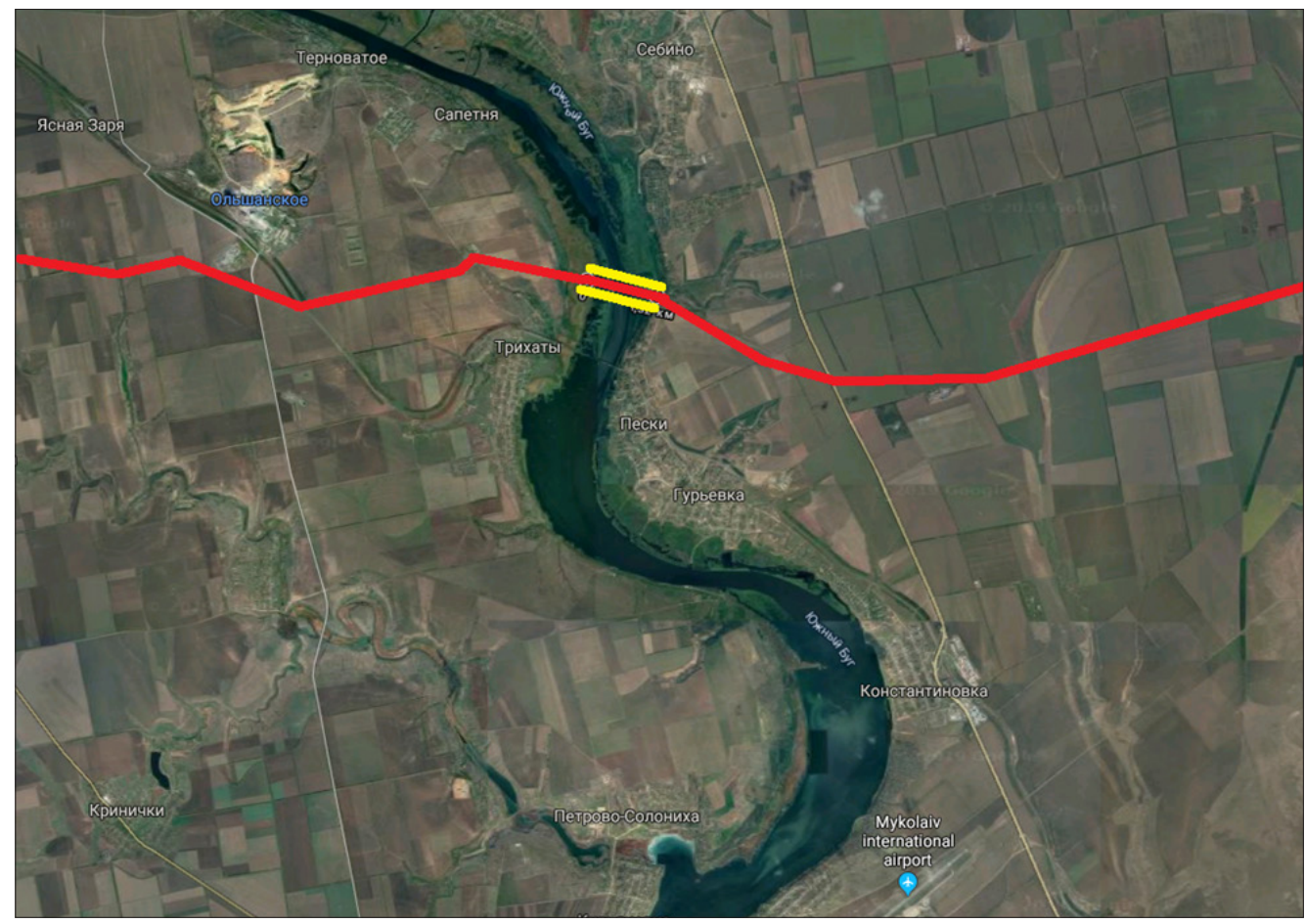

Pис. 2. Шлях аміакопроводу поблизу населених пунктів 


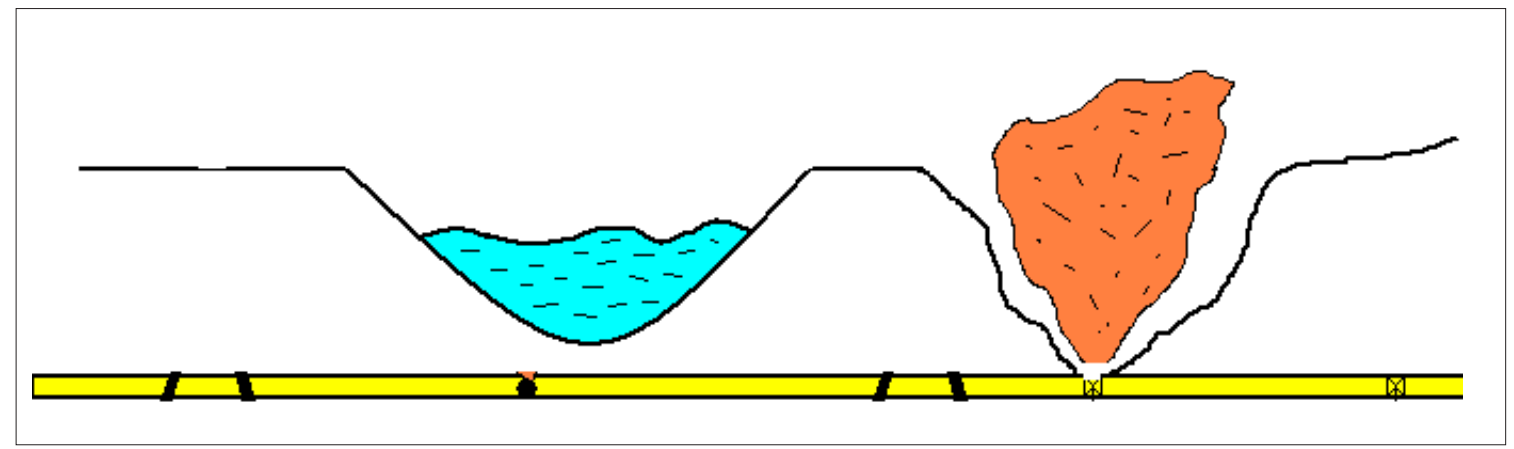

Рис. 3. Викид $\mathrm{NH}_{3}$ з аміакопроводу

На рис. 2 червоним позначено шлях аміакопроводу, а жовтим - його перехід під річкою Південний Буг.

Міністерством із надзвичайних ситуацій України розроблена та затверджена «Методика прогнозування наслідків розливу (викиду) хімічно небезпечних речовин при аваріях на промислових об'єктах і транспорті» (Наказ № 73/82/64/122 від 27 березня 2001 р.).

Ця методика застосовується для речовин, які зберігаються у газоподібному або рідкому стані, та передбачає довгострокове (оперативне) й аварійне прогнозування. Вона передбачає проведення розрахунків для планування заходів щодо захисту населення у приземному шарі повітря на висотах до $10 \mathrm{M}$.

Довгострокове прогнозування здійснюється заздалегідь для визначення можливих масштабів забруднення, сил і засобів, потрібних для проведення аварійно-рятувальних робіт, для складання оперативно-плануючих та інших документів.

Для довгострокового прогнозування потрібно мати такі вихідні дані:

1) глибину зони зараження - Г, км;

2) площу зони зараження - S, км²;

3) час підходу хмари НХР до заданого об'єкта $-\tau_{\text {підх, }}$ годин;

4) тривалість вражаючої дії НХР $-\tau$ НХР, годин;

5) можливі втрати людей $-\mathrm{N}_{\mathrm{n}}$, осіб.

Результати прогнозу хімічної обстановки наносяться на топографічні карти або плани міста чи об'єкта.

Основний параметр, що характеризує поширення НХР при викиді або розлитті у навколишнє середовище, називається глибиною зони зараження.

Прогнозування глибини зони хімічного зараження НХР полягає у визначенні глибини зони зараження для еквівалентної кількості хлору за первинною і вторинною хмарами.

За табличними даними визначаємо глибину зони ураження (Г $)$ як 0,6209 км, інтерполяційно з табличних даних (у [4] табл. 5.5). Для остаточного рішення про глибину зони зараження необхідно визначити глибину зони зараження $\Gamma_{\tau}$ що сформувалася на момент часу, який минув із початку аварії:

$$
\Gamma_{\tau}=\tau \cdot \text { Vпер, км, }
$$

де $\tau$ - час від початку аварії (початку виходу НХР), год (встановимо $\tau=1$ год);

$\mathrm{V}_{\text {пер }}$ - швидкість перенесення переднього фронту зараженого повітря $(=3,5 \mathrm{~m} / \mathrm{c}=12,6$ км/год при конвекції та швидкості вітру $0,5 \mathrm{~m} / \mathrm{c})$.

$$
\text { Так } \Gamma_{\tau}=12,6 \text { км. }
$$

Порівнюючи значення глибини $\Gamma_{0}$ зони зараження при дії первинної та вторинної хмар із можливою глибиною зони $\Gamma_{\tau}$, сформованої на конкретний момент часу після початку аварії, вибираємо менше 3 цих значень $-\Gamma=\min \left(\Gamma_{0}, \Gamma_{\tau}\right)$, км.

Остаточною оцінкою глибини зони зараження $€$ $\Gamma=\Gamma_{0}=0,6209$ км.

Визначаємо площу хімічного зараження.

Зона хімічного зараження є сектором. Площа зони хімічного зараження $\mathrm{S}$ визначається за формулою:

$$
\mathrm{S}=8,72 \cdot 10^{-3} \cdot \Gamma^{2} \cdot \mathrm{f}^{0}, \mathrm{\kappa м},
$$

де $\mathrm{f}^{0}-$ кутові розміри зони можливого зараження, град, залежить від швидкості приземного вітру ( $=360^{\circ}$ для швидкості вітру $0,5 \mathrm{M} / \mathrm{c}$ ).

$$
\mathrm{S}=1.21 \mathrm{\kappa м}^{2}=1210229 \mathrm{M}^{2}
$$

Площа $\mathrm{S}$ зони зараження - це площа максимально можливої зони зараження. У конкретний момент часу $\tau$, що минув після початку аварії (виходу або викиду $\mathrm{HXP}$ ), площа зони - позначимо іiі $\mathrm{S} \tau$ - буде меншою, тобто $\mathrm{S} \tau<\mathrm{S}$. Площа $\mathrm{S} \tau$ обчислюється за формулою:

$$
\mathrm{S}_{\tau}=\mathrm{k}_{8} \Gamma^{2} \cdot \tau^{0,2}, \mathrm{KM}^{2} \quad \text { при } \tau<\tau_{\text {вип }}
$$

де $\mathrm{k} 8$ - коефіцієнт, що залежить від ступеня вертикальної стійкості повітря, приймається рівним 0,233 при конвекції.

За результатом розрахунку $\mathrm{S}_{\tau}=0,0898$ км$^{2}$, при часі $\tau=1$ год. На рис. 4 наведено приблизну зону ураження зі збереженням форми. Вірогідно, що хмара буде мати округлу форму через поширення рівномірно у всі боки (за таких погодних умов).

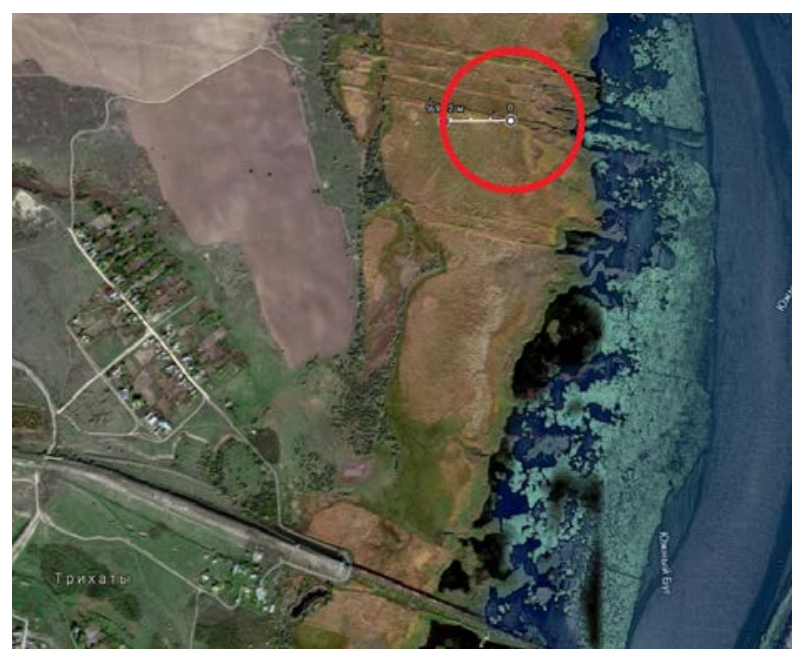

Рис. 4. Приблизна зона ураження за 1 годину після витоку аміаку 
Спрогнозуємо час підходу зараженої хмари та тривалості вражаючої дії НХР.

Час підходу хмари НХР до заданого об'єкта залежить від швидкості перенесення хмари повітряним потоком і визначається за формулою:

$$
\tau_{\operatorname{mixx}}=\frac{\mathrm{L}}{\mathrm{V}_{\text {пер }}} \text {, год, }
$$

де L - відстань від джерела зараження до об’єкта, км.

Розрахунки будуть відбуватися для одразу 3 об'єктів - с. Трихати, с. Піски та с. Себіно. За розрахункову L було прийнято відстань до найближчого житлового будинку: 1 км - Трихати, 1,63 км - Піски, 1,72 км - Себіно.

Проведені розрахунки передбачають, що при розрахунку для кожного населеного пункту напрям вітру буде у бік цього ж населеного пункту. Так, за розрахунками $\tau_{\text {підх }}=0,079$ год $=4,76$ хв для Трихат, $\tau_{\text {підх }}=0,129$ год $=$ 7,76 хв для Пісків, $\tau_{\text {пілх }}=0,136$ год $=8,19$ хв для Себіно.

Для прогнозування можливих втрат людей необхідно визначити зону хімічного ураження. За нанесеною на карту обстановкою обчислимо вірогідну площу ураження $\mathrm{S}_{\text {п }}$ - частину населеного пункту (рис. 5, рис. 6).

Очікувані втрати людей залежать насамперед від кількості людей $\mathrm{N}$, присутніх у зоні зараження. Ця кількість $\mathrm{N}$ визначається за формулою: $\mathrm{N}=\mathrm{S} \cdot \rho_{\text {нас }}$, де $\mathrm{S}$ - площа зони зараження, км²; $\rho_{\text {нас }}-$ щільність населення в зоні зараження, чол/ $\mathbf{M}^{2}$.

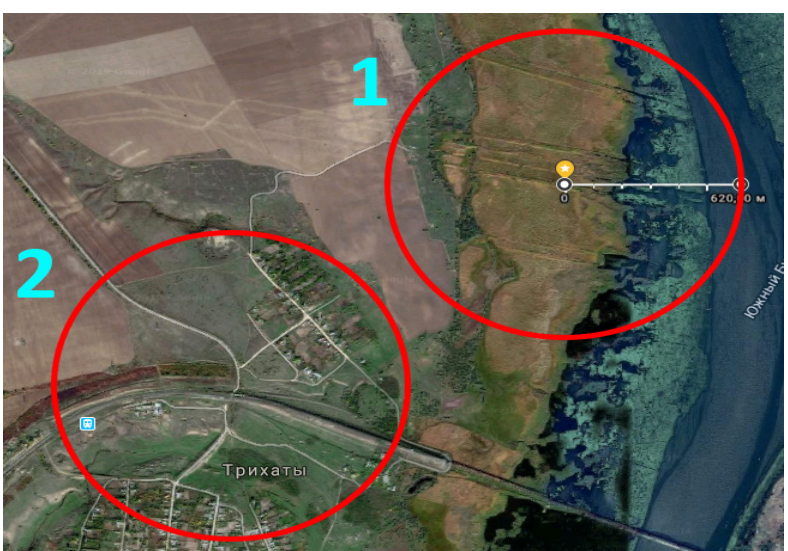

Рис. 5. Зміщення хмари (1) до найближчих будинків у с. Трихати (2)

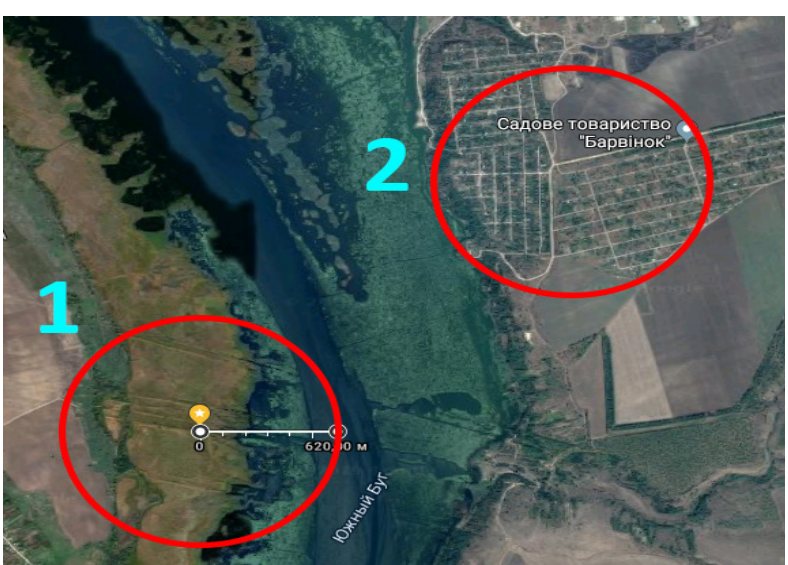

Рис. 6. Зміщення хмари (1) до найближчих будинків у с. Себіно (2)

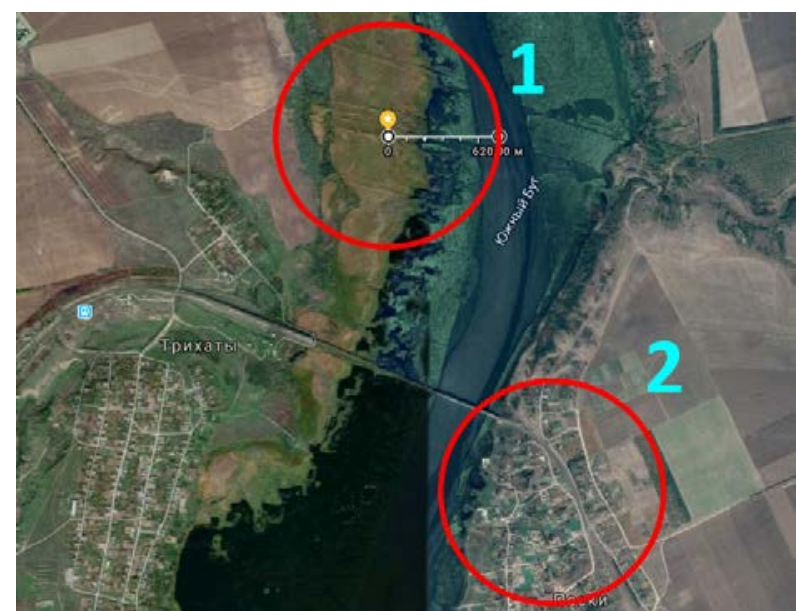

Рис. 7. Зміщення хмари (1) до найближчих будинків у с. Піски (2)

За щільність населення в зоні ураження:

- в с. Трихати візьмемо $\rho_{\text {нас }}=0,0001$ чол $/ \mathrm{M}^{2}$;

- $\quad$ в с. Себіно $-\rho_{\text {нас }}=0,0004$ чол/ $\mathrm{M}^{2}$;

- $\quad$ в с. Піски $-\rho_{\text {нас }}=0,0001$ чол/ $\mathrm{M}^{2}$.

Ці значення отримані аналітично.

Результати розрахунку кількості людей такі:

- $\quad \mathrm{N}=170$ люд. для с. Трихати;

- $\quad \mathrm{N}=110$ люд. для с. Піски;

- $\quad \mathrm{N}=502$ люд. для с. Себіно.

Очікувані втрати людей Nn у зоні зараження дорівнюють:

$$
\mathrm{N}_{\mathrm{n}}=\mathrm{k}_{\mathrm{e}} \cdot \mathrm{k}_{\mathrm{n}} \cdot \mathrm{k}_{3} \cdot \mathrm{N}, \text { чол., }
$$

де $\mathrm{k}_{\mathrm{e}}$ - коефіцієнт, що враховує евакуацію населення (в цьому розрахунку $=0,7$ );

$\mathrm{k}_{\mathrm{n}}$ - коефіцієнт, що враховує умови перебування людей (відкрито, у квартирах, в укриттях) (у цьому розрахунку $=0,5$, оскільки не всі зможуть провести герметизацію приміщення);

$\mathrm{k}_{3}$ - коефіцієнт, що враховує забезпеченість населення індивідуальними засобами захисту (у цьому розрахунку $=1$, тобто люди не забезпечені).

Так, для с. Трихати $\mathrm{N}_{\mathrm{n}}$ становить 60 чол. (35\%), для с. Піски $\mathrm{N}_{\mathrm{n}}=39$ (35\%), для с. Себіно $\mathrm{N}_{\mathrm{n}}=176$ (35\%).

Отже, ураження людей мають середньо-важкий ступінь.

Висновки. У нашій роботі було проведено оглядове дослідження впливу можливої аварії на ділянці аміакопроводу «Тольятті - Одеса» на території Миколаївської області.

Ділянка припустимої аварії проходить поблизу сіл Піски, Трихати та Себіно.

У пункті 1 було наведено загальну інформацію та технічні характеристики аміакопроводу. У другому пункті було розглянуто потенційні аварії на аміакопроводі та способи протидії їм. У пункті 3 було проведено розрахунок кількості потенційних втрат серед населення кожного з розташованих поблизу сіл внаслідок аварії на аміакопроводі. У пункті 4 було наведено способи протидії дії аміаку на людей і наведено інформацію щодо дії аміаку на людей та інші живі організми, наприклад, рослини. 
Для розрахунку було використано методику прогнозування наслідків розливу (викиду) хімічно небезпечних речовин при аваріях на промислових об'єктах і транспорті, розроблену і затверджену Мiністерством із надзвичайних ситуацій України (Наказ № 73/82/64/122 від 27 березня 2001 р.). Ознайомитися з методикою можна за посиланням [4].

За проведеними розрахунками було отримано такі результати. За умов: швидкість вітру - 0,5 м/с, час доби - день, погода - ясна, температура повітря - $40^{\circ} \mathrm{C}$ :
- площа ураження хмари випаруваного внаслідок контакту з повітрям аміаку $-1,21$ км² $^{2}$;

- $\quad$ в кожному варіанті зміщення хмари в бік одного із селищ хмара прибуде туди в середньому за 7 хв.

Очікувані втрати серед населення можна вважати середньо-важкими, оскільки кількість потенційних втрат для с. Трихати - 60 чол.; с. Піски - 39; с. Себіно - 176.

У кожному з варіантів -це $35 \%$ населення у зоні ураження. Також було подано короткий зміст аварійно-рятувальних робіт під час аварій із виходом НХР i дії місцевого населення.

\section{Список літератури:}

[1] Мельник С.В., Цабієв О.М., Бондар I.О. Прогнозування екологічного ризику для міста Одеси у разі аварійного викиду аміаку з припортового заводу.

[2] Грабар О.В., Лихачова В.В., Рисенко Г.О. Екологічна безпека та надійність експлуатації магістрального аміакопроводу. Вісті Автомобільно-дорожнього інституту. 2010. № 2 (11).

[3] Затинайченко Д.О. Прогнозування забруднення атмосфери та р. Дніпро у випадку аварії на аміакопроводі «Тольятті - Одеса»

[4] Рятувальні роботи під час ліквідації надзвичайних ситуацій. Ч. 1 : посібник / за заг. ред. В.Н. Пшеничного. Київ : Основа, 2006. 240 с.

[5] Как устроен аммиакопровод. Трансаммиак. URL: http://transammiak.com/index.php?location=ammiak\&sess $=45893 \mathrm{e} 507 \mathrm{~d} 39 \mathrm{~b} 753 \mathrm{a} 7073 \mathrm{ec} 4 \mathrm{a} 9 \mathrm{~d} 36705$.

[6] Оценка риска аварий на магистральном аммиакопроводе «Тольятти - Одесса» / Ю.А. Дадонов, Д.В. Дегтярев, И.А. Кручинина, М.В. Лисанов, С.И. Сумской, В.Е. Бурдачев. Наука и техника. 2003.

(C) Дубінін В. А., Бродовська А. В. Дата надходження статті до редакції: 25.06.2020 Дата затвердження статті до друку: 27.07.2020 